KOŚCIÓŁ I PRAWO 8(21) 2019, nr 1, s. 29-50

DOI: http://dx.doi.org/10.18290/kip.2019.8.1-3

\author{
Monika Menke
}

\title{
POZYCJA PRAWNA KATOLICKICH WYDZIAŁÓW TEOLOGICZNCH NA TERYTORIUM REPUBLIKI CZESKIEJ OD 1950 ROKU
}

Czeskie wydziały teologiczne swoją tradycją sięgają stuleci. W części pierwszej artykułu zostaną ukazane konsekwencje dojścia do władzy reżimu komunistycznego, co po 1948 r. wniosło obostrzenie nadzoru państwa nad Kościołami i znaczne utrudnienia w studiowaniu teologii katolickiej i niekatolickiej. Następnie mowa będzie o pewnym krótkim złagodzeniu relacji w czasie tzw. „Praskiej wiosny” (1968), które wkrótce zmieniło się w ostry nadzór w okresie normalizacji. W artykule zostanie scharakteryzowana także odnowa wydziałów teologicznych ${ }^{1}$ po 1990 r. do czasów współczesnych. W tym okresie ma miejsce stopniowa rozbudowa tych uczelni, połączona z poszukiwaniem ich specyficznego miejsca w społeczeństwie czeskim. Erygowanie WT ze strony władz kościelnych stanowi w obecnym systemie prawnym Republiki Czeskiej ${ }^{2}$ przejaw autonomii kościołów i wspólnot wyznaniowych, gwarantowanych ustawowo ${ }^{3}$.

Dr MoniKa Menke - adiunkt, Katedra Historii Kościoła i Prawa Kanonicznego, Cyrylometodiański Wydział Teologii Uniwersytetu Palackiego w Ołomuńcu; adres do korespondencji: Na Hradě 2, 77900 Olomouc, Republika Czeska; e-mail: monika.menke@upol.cz; https://orcid.org/0000-0002-2814-2524

${ }^{1}$ Dalej cyt.: WT.

${ }^{2}$ Dalej cyt.: RCz.

${ }^{3}$ Ustawa nr 3/2002 ZU o wolności wyznania religijnego i sytuacji prawnej Kościołów i związków wyznaniowych, $\S 6, \mathrm{nr} 3$. 


\section{DZIAŁANIA WŁADZ KOMUNISTYCZNYCH PRZECIWKO WYDZIAŁOM TEOLOGICZNYM W 1950 ROKU}

Przed 1950 r. na terenie obecnej RCz działały dwa katolickie WT (w Pradze i Ołomuńcu), a oprócz nich szkoły teologiczne diecezjalne [Novotný 2007a, 47-48] ${ }^{4}$ i zakonne [tamże, 49] ${ }^{5}$. Ramy prawne WT nadawała konstytucja apostolska Piusa XI Deus scientiarum Dominus z 1931 r. oraz przepisy wykonawcze Świętej Kongregacji Seminariów Duchownych i Uniwersytetów ${ }^{6}$. W ustawodawstwie czechosłowackim recypowane były w dwóch dekretach rządowych z 1937 r. ${ }^{7}$ Akatolicy studiowali na sześciu pozostałych wydziałach i szkołach teologicznych [Kaplan 1993, 402] ${ }^{8}$.

Reżim komunistyczny wszystkie te szkoły zredukował do jedynego oficjalnego katolickiego WT i dwóch wydziałów akatolickich ${ }^{9}$. Podstawą prawną ingerencji wobec studiów teologicznych stała się ustawa nr 58/1950 ZU o uczelniach wyższych ${ }^{10}$, dzięki której WT zostały wyjęte z uniwersytetów (ze względu na rzekomą antynaukowość teologii) i podporządkowane jedynie utworzonemu w 1949 r. Państwowemu Urzędowi ds. Wyznańn ${ }^{11}$, zaś

${ }^{4}$ Seminaria w Litomierzycach, Czeskich Budziejowicach, Hradec Králové, Brnie i Widnawie (tylko do II wojny światowej).

${ }^{5}$ Zakład Teologiczny Redemptorystów w Oborziszti, Generalna Filozoficzna i Teologiczna Szkoła Dominikańska w Ołomuńcu, Kapucyńskie Studium Filozoficzne w Ołomuńcu, Kapucyńskie Studium Teologiczne w Pradze, jedynie formalnie istniejące Franciszkańskie Studium Teologiczno-Filozoficzne w Hájku, Salezjański Filozoficzny Zakład Studyjny w Přestavlkách i Frysztaku i Szkoła Teologiczna w Oseku koło Duchcova, oraz Instytut Filozoficzny Towarzystwa Jezusowego w Dzieczynie (Děčín).

${ }^{6}$ Pius PP. XI, Constitutio apostolica Deus Scientiarum Dominus de universitatibus et facultatibus studiorum ecclesiasticorum (24.05.1931), AAS 13 (1931), s. 241-84.

${ }^{7}$ Dekret rządowy $\mathrm{nr}$ 151/1937 ZU o studium i egzaminach na katolickich wydziałach teologicznych (18.06.1937) i Dekret rządowy $\mathrm{nr}$ 152/1937 o realizacji podstawowych założeń nt. studiów i egzaminów na katolickich wydziałach teologicznych (28.06.1937).

8 Czechosłowacki Ewangelicki WT im. Husa w Pradze, Seminarium Duchowne Cerkwi Prawosławnej w Pradze, Zakład Biblijny Jednoty Českobratrské w Kutné Hoře, Seminarium Teologiczne Baptystów Czechosłowackich w Pradze, Seminarium Kościoła Adwentystów Dnia Siódmego w Pradze i Kurs Kaznodziejski Kościoła Czechosłowackiego w Pradze. Na Słowacji były to Ewangelicki WT (wyznania augsburskiego) w Bratysławie, Prawosławny Kurs Teologiczny w Michalowcach i kursy dla kantorów w Banskiej Szczawnicy.

9 Komenská evangelická bohoslovecká fakulta v Praze a Husova československá bohoslovecká fakulta v Praze. Ten sam dekret erygował formalnie również Prawosławny WT w Pradze, który jednakże miał swoją siedzibę w Preszowie na Słowacji.

${ }^{10}$ Ustawa nr 58/1950 ZU o uczelniach wyższych (18.05.1950), § 33-34.

${ }^{11}$ Dalej cyt.: SÚC. 
po jego likwidacji w 1956 r. Ministerstwu Kultury [Jäger 2009, 781-82] ${ }^{12}$. Do ustawy tej nawiązał dekret rządowy nr 112/1950 ZU o WT, który de facto i de iure zlikwidował: Cyrylo-Metodiański WT w Ołomuńcu, diecezjalne szkoły teologiczne w Litomierzycach, Czeskich Budziejowicach, Brnie i Hradec Králové oraz wszystkie zakonne szkoły teologiczne działające na terenie $\mathrm{kraju}^{13}$. Inteligencja katolicka mogła więc legalnie studiować jedynie w Katolickim WT w Pradze (później przeniesionym do Litomierzyc w Czechach Północnych), niebędącym częścią uniwersytetu. W 1950 r. SÚC ogłosił również „Statut Organizacyjny dla WT”, zgodnie z którym wydział finansowany był przez państwo, decydujące o stanowiskach dziekana i prodziekanów, nadawaniu tytułów profesora i docenta oraz o przyjmowaniu kandydatów na studia. Miejscowe seminarium potraktowane zostało jako część WT służąca do zakwaterowania i stołowania studentów oraz ich wychowania stanowego. Przełożonych seminaryjnych ustanawiał SÚC. Studia na WT określono od 1950 r. tylko jako czteroletnie. Pierwszym dziekanem został V. Šanda, w latach 1952-1954 zastąpiony przez J. Hronka, po nich funkcję tę pełnił biblista J. Merell, który aż do końca swej kadencji (1974) [Novotný 2007a, 416] starał się, pomimo pewnych kompromisów, o utrzymanie kościelnego charakteru studiów teologicznych.

Reakcja kleryków i społeczeństwa na ten nowy stan była na początku odmowna. Reprezentanci Kościoła oraz lud katolicki uważali istnienie wydziału erygowanego przez państwo za nieuprawnione i antykościelne; jednakże w okresie, gdy większość czeskich i morawskich biskupów została już odizolowana od wiernych i internowana, zaś w kuriach biskupich działali pełnomocnicy państwowi, nie były możliwe wspólne konsultacje i poszukiwanie innych rozwiązań. Przed końcem września 1950 r. opór został złamany, głównie dzięki stanowisku arcybiskupa Ołomuńca Karla Matochy, którego dziekan V. Šanda przekonał w swym piśmie, iż w obecnej sytuacji nie sposób działać inaczej, a przepisy kanoniczne zostaną na wydziale utrzymane i jurysdykcja biskupów wobec kleryków będzie respektowana i być może dojdzie do przeniesienia niektórych wykładowców z Ołomuńca na nowy scentralizowany WT [tamże, 12-23] ${ }^{14}$. Ordynariusza praskiego

${ }^{12}$ SÚC został zlikwidowany dekretem rządu nr 19/1956 ZU, § 2. Sprawami WT zajmował się aż do 1969 r. Sekretariat ds. Kościelnych (SVC) Ministerstwa Kultury.

${ }^{13}$ Zakonne szkoły teologiczne faktycznie przestały istnieć na skutek przejęcia klasztorów i internowania osób konsekrowanych w ramach tzw. „Akcji K” w kwietniu 1948 r.

${ }^{14}$ Korespondencja Šandy z Matochą skutkowała kilkoma listami abpa Matochy: do jego kleryków, byłych wykładowców ołomunieckiego WT, a w końcu do SÚC, gdzie 
abpa Berana, internowanego w swej rezydencji, odwiedził pełnomocnik rządowy i SÚC, by przekonać go do wydania zgody na działalność seminarium i wydziału na terytorium swojej diecezji, jaką w ostateczności uzyskał. Udzielone zostały misje kanoniczne dla wykładowców. Bezpośrednia reakcja Stolicy Apostolskiej na tę redukcję studiów teologicznych w Czechosłowacji nie została na razie przebadana w sposób dostateczny. Pośrednio jednak reakcja była analogiczna, jak wobec innych form prześladowania ze strony reżimu: z konieczności tolerowano stan faktyczny [tamże, 128-30] ${ }^{15}$. W 1950 r. studia rozpoczęło tylko 138 kleryków [Balík i Hanuš 2007, 113] ${ }^{16}$ na wszystkich kursach i rocznikach w ramach późniejszego wydziału litomierzyckiego: klerycy, którzy odmówili immatrykulacji, najpierw przeszli do zatrudnienia cywilnego, lecz od września 1950 r. byli w większości wzywani do służby wojskowej w tzw. pomocniczych hufcach pracy (PTP). Do nauczania na WT włączono kursy z marksizmu-leninizmu. Zgłoszenia kandydatów $\mathrm{z}$ odpowiednim profilem kadrowym i w ramach kwot określonych dla danej diecezji (tzw. numerus clausus) wysyłał pełnomocnik państwowy do sekretarza wydziału w przesyłce o charakterze „poufnym”, a w sprawie zdatności każdego kandydata zabierał głos wojewódzki pełnomocnik ds. wyznań [Demel 2001, 63-65]. Wobec tak ograniczonych możliwości oficjalnych, niezależnych studiów teologicznych wkrótce zaczęły pojawiać się alternatywne możliwości, wymuszone przez wyjątkową sytuację w CSRS. Zgodnie z kan. $976 \S 3 \mathrm{KPK} / 17$ wymagano, by studium teologiczne nie przebiegało prywatnie, lecz w szkołach ustanowionych zgodnie z prawem. Jednakże kan. $972 \mathrm{KPK} / 17$ umożliwiał kandydatom do święceń prezbiteratu przebywanie poza seminarium pod warunkiem, iż opiekuje się nimi odpowiedni kapłan

Matocha informował o zmianie stanowiska w sprawie wydziału, na który kieruje swych alumnów. Zwraca jednak uwagę na konieczność uzyskania dla nowopowstałego wydziału o charakterze interdiecezjalnym zatwierdzenia przez Rzym, wskazując na kan. 1354 § 3 i 1357 § 4 Kodeksu Prawa Kanonicznego z 1917 r., zob. Codex Iuris Canonici Pii X Pontificis Maximi iussu digestus Benedicti Papae XV auctoritate promulgatus (27.05.1917), AAS 9 (1917), pars II, s. 1-593 [dalej cyt.: KPK/17].

15 Annuario Pontificio z 1957 r. podaje wciąż Pragę i Ołomuniec (jako wydziały kościelne na uniwersytetach państwowych). Od lat 60 . wydziały te podawane są bez powiązania $\mathrm{z}$ konkretnym uniwersytetem i bez daty erygowania.

${ }^{16} \mathrm{~W}$ zestawieniu z zakładaną liczbą tysiąca, co dla rządzących oznaczało porażkę. Dlatego w następnych latach miały miejsce organizowane przez reżim rekrutacje, nieodzwierciedlające starań o dostateczną liczbę nowych kapłanów, gdyż po tym, jak wygasał początkowy opór wobec scentralizowanemu wydziałowi, określono dla każdej diecezji numerus clausus dla liczby kleryków. Polityka ta miała na celu ciągłe obniżanie stanu duchowieństwa i utrzymała się aż do upadku reżimu jesienią 1989 r. 
i uzyskali dyspensę ordynariusza. Na ten przepis zwykle powoływali się studenci, którzy odbywali studia potajemnie lub prywatnie ${ }^{17}$.

Dalszą przełomową datą dla praskiego seminarium i WT okazał się rok 1953. W wyniku reformy szkolnictwa studia wydłużono do lat pięciu ${ }^{18}$. Budynek WT w Dejvicach został zajęty przez wojsko i obie instytucje eksmitowane zostały do pomieszczeń byłego seminarium diecezjalnego i kapituły w Litomierzycach, gdzie pozostały aż do 1990 r. Znacząca była już sama nazwa: Rzymskokatolicki Cyrylo-Metodiański WT w Pradze z siedzibą w Litomierzycach. Przeniesienie przyniosło ze sobą zmiany kadrowe wśród wykładowców. Dziekan Hronek, którego co prawda wybrano w 1954 r. na dalszą kadencję, zmarł we wrześniu tegoż roku, zastąpiony został przez prof. J. Merella, biblistę - specjalistę od Nowego Testamentu, który mniej od swych poprzedników szedł na rękę reżimowi i kierował wydziałem aż do 1974 r. Seminarium do 1959 r. kierował rektor F. Panuška, redemptorysta i moralista, który potrafił to robić utrzymując mocny rygor wewnętrzny. Koncepcja ideowa wydziału była w owym czasie neoscholastyczna, zaś grono wykładowców wywodziło się w większości z okresu międzywojennego. Spadek poziomu nastąpił dopiero po $1962 \mathrm{r}$. Nie można jednak twierdzić, iż WT znalazł się w nieodpowiednich rękach - niektórzy z wykładowców byli w pełni porównywalni z ówczesnym stanem nie tylko katolickich, ale też akatolickich WT. Podręczniki i literatura dla studiów teologicznych była jednak proweniencji jedynie domowej i przestarzała, zaś teologia jako dyscyplina naukowa została pozbawiona perspektyw pracy akademickiej i możliwości publikacyjnych ${ }^{19}$ oraz możności kontaktów z zagranicą. W kwietniu 1957 r. Ministerstwo Szkolnictwa wydało oficjalne „Wytyczne do egzaminów wstępnych na WT”, po których pojawiły się podobne instrukcje w kolejnych latach, w konsekwencji czego ilość przyjętych studentów szybko malała. Minimum (7) nastąpiło w roku akademickim 1962-1963 [Novotný 2007a, 418].

${ }^{17} \mathrm{~Np}$. u swych wykładowców z byłych szkół diecezjalnych lub zakonnych, zwykle w obozach pracy lub internowania, czy wręcz w warunkach więziennych [Vlček 2004, 87-94].

${ }^{18}$ Ustawa $\mathrm{nr}$ 31/1953 ZU o szkolnictwie $i$ ksztatceniu nauczycieli (7.05.1953), wprowadzająca ośmioletni obowiązek szkolny, skracająca okres szkoły średniej o dwa lata poprzez instytut tzw. szkół jedenastoletnich, co częściowo miało kompensować wydłużenie okresu studiów akademickich o jeden rok.

${ }^{19}$ Możliwe było jedynie pisanie artykułów do periodyków „Duchovní pastýř”, „Katolické nowiny”, wydawanie w układzie zamkniętym koniecznych skryptów (1 lub 2 pozycje rocznie), zaś dotyczyło to tylko autorów mających zaufanie władz państwowych. 
Do stopniowego ożywienia zaczęło dochodzić wraz z Soborem Watykańskim II (1962-1965), przebieg którego Kościół czeski śledził zarówno z prasy oficjalnej, jak i przede wszystkim z audycji rozgłośni zagranicznych. Dziekan WT Merell został nawet członkiem oficjalnej czeskiej delegacji w charakterze doradcy teologicznego. W 1965 r. po wymuszonym wyjeździe nowo zamianowanego kard. Josefa Berana do Rzymu administratorem apostolskim zamianowany został praski biskup František Tomášek, który stał się Wielkim Kanclerzem WT w Litomierzycach. Liczba studentów (wciąż limitowana przez kwoty państwowe) zaczęła się podnosić i opracowany został perspektywiczny plan wydziału (1966-1967). Proponował rozważenie zarówno powrotu WT do Pragi (do tego nie doszło), jak i poszerzenie grona wykładowców, przez Sobór zalecane powstanie katedry liturgiki, umożliwienie studiów zagranicznych nauczycielom akademickim, poszerzenie możliwości działalności publikacyjnej, itp. [tamże, 191].

\section{PRASKA WIOSNA 1968 ROKU \\ A JEJ SKUTKI W ODNIESIENIU DO ISTNIENIA WYDZIAŁÓW TEOLOGICZNYCH}

Jako „Praska wiosna” nazywany jest okres pierwszej połowy 1968 r., gdy odwilż w warunkach społeczno-politycznych miała swe odbicie również w relacjach wobec kościołów. W kwestii studium teologii skutki rozluźnienia były zauważalne ok. 1974 r., kiedy doszło do ponownego obostrzenia sytuacji społecznej na skutek tzw. normalizacji. Najbardziej doniosłą zmianą było otwarcie filii wydziału praskiego w Ołomuńcu z dniem 1 września 1968 r. wraz $\mathrm{z}$ odnowieniem tamtejszego seminarium duchownego. W części litomierzyckiej wydziału stopniowo odnawiało się grono pedagogiczne, prowadzone były rozmowy w sprawie możliwości reintegracji WT do Uniwersytetu im. Karola, otwarto ponownie kurs katechetyczny, założone zostało zrzeszenie studentów-kleryków, ustanowiono katedrę liturgiki. Bp Tomášek podał do wiadomości, iż WT nadal uważany jest przez Kongregację ds. Wychowania Katolickiego za legalny wydział archidiecezji praskiej, pomimo iż ma swą siedzibę w Litomierzycach - jest uważany za bezpośredniego następcę dotychczasowego WT w Pradze. Egzaminy wstępne zwolnione zostały z nadzoru politycznego (doszło do zniesienia numerus clausus, przywróconego ponownie w 1970 r.), więc mogli zostać przyjęci studenci dotychczas 
„politycznie niewłaściwi”, lub też ci, którzy część studiów odbywali w ukryciu. Studium eksternistyczne zostało umożliwione również niektórym świeckim i zakonnikom [tamże, 216-20] (zakony męskie skazane były od $1950 \mathrm{r}$. na banicję).

Byli wykładowcy wydziału ołomunieckiego zwrócili się w kwietniu 1968 r. w memorandum do konsystorza kapituły, domagając się odnowienia miejscowego WT i seminarium. Konsystorz poparł to żądanie, uzupełnił o analizę stanu duchowieństwa i kleryków na Morawach i na Śląsku oraz o propozycję regulacji wydatków bieżących wydziału. Zwrócił także uwagę na wysokie zainteresowanie studiami teologii w gronie świeckich [Cekota 1996, 48]. Ponieważ jednak do rozpoczęcia roku akademickiego nie pozostało wiele czasu, wszczęto rokowania dotyczące możliwości erygowania przynajmniej zamiejscowej filii ołomunieckiej praskiego wydziału z siedzibą w Litomierzycach, na co Ministerstwo Kultury wyraziło zgodę dnia 16 września 1968 r., tymczasowo w zakresie dwu roczników. W Ołomuńcu pierwotny budynek WT zajęty był przez wydział pedagogiczny i uniwersytet nie miał woli uwolnienia go. Seminarium i WT mieściły się więc $\mathrm{w}$ rezydencji arcybiskupów ołomunieckich $\mathrm{w}$ bardzo skąpych warunkach. Pomimo tego zainteresowanie studiami było znaczne: na I rok zgłosiło się wówczas 51 kleryków (20 z archidiecezji ołomunieckiej, 27 z diecezji brneńskiej i 4 z administratury apostolskiej czeskocieszyńskiej), na II rok 23 kleryków, zaś do dwuletniego studium katechetycznego - 114 świeckich (łącznie 128 studentów) [tamże, 49]. Ponieważ była to tylko filia wydziału litomierzyckiego, placówka ołomuniecka nie posiadała swego dziekana (tym był litomierzycki prof. J. Merell), lecz tylko prodziekana, którym przez krótki okres jej trwania był historyk dr Bohumil Zlámal. W skład grona pedagogicznego, oprócz niektórych z wykładowców sprzed 1950 r., weszło też kilku nowych [Pojsl 2010, 41] ${ }^{20}$. Na wydziale widoczny był mocny wpływ soborowy, a wśród studentów były także kobiety. Pomimo wszelkich starań prodziekana Zlámala, V. Tkadlčíka, rektora seminarium, dra L. Dýmala i interwencji ołomunieckiego wikariusza kapitulnego Josefa Vrany, który skierował w tej sprawie bezpośrednie pismo do prezydenta państwa Ludvíka Svobody, filii ołomunieckiej nie udało się utrzymać i została z dniem

${ }^{20}$ Od 1968 r. wykładowcami byli: dr A. Kleveta - Stary Testament i języki biblijne, dr J. Luska - liturgika, dr E. Pluhař - teologia moralna, dr B. Zlámal - historia Kościoła, dr J. Olejník - śpiew kościelny, dr J. Ryška - prawo kanoniczne, dr V. Tkadlčík - język cerkiewnosłowiański. 
30 czerwca 1974 r. zniesiona [tamże, 42] (ponownie wraz z seminarium ołomunieckim) w ramach postępującej normalizacji decyzją SVC. Od tej pory oficjalne studium teologii katolickiej wraz z formacją do kapłaństwa możliwe było jedynie w litomierzyckiej filii praskiego WT. Ponowne ograniczenie oficjalnych WT jednakże zainspirowało powstanie alternatywnych form studiów. Po 1970 r. zaczęto przygotowywać zorganizowane tajne kursy studyjne, najczęściej w ramach poszczególnych zakonów ${ }^{21}$, u niektórych teologó $\mathrm{w}^{22}$, kapłanów $\mathrm{w}$ duszpasterstwie oficjalnym, ewentualnie tė̇ zagranicą ${ }^{23}$. Owe nieoficjalne formy studiów kształtowały w sposób istotny historię czeskiej teologii katolickiej 2. połowy XX w. i również dzięki nim mogły zostać odnowione po zmianie reżimu kadry wykładowców odnowionych WT [Novotný 2007b, 94].

\section{OKRES NORMALIZACJI I DZIAŁALNOŚCI WYDZIAŁÓW TEOLOGICZNYCH DO KOŃCA REŻIMU TOTALITARNEGO}

Jako normalizacja określany bywa w kontekście CSRS okres od zdławienia przemocą procesu „Praskiej wiosny” wojskami Układu Warszawskiego w 1968 r. (ewentualnie od konsekwencji tego wydarzenia) aż do tzw. rewolucji aksamitnej w listopadzie 1989 r. W Kościele czeskim był to równocześnie okres prób przynajmniej częściowego wdrażania postanowień Soboru (choć w wymiarze bardzo wąskim, bo ograniczającym się w za-

${ }^{21}$ Własną formację i studia prowadzili więc franciszkanie, dominikanie, jezuici, salezjanie [Černušák, Prokop, i Němec 2001, 203]. Np. u dominikanów ci studenci, którzy mogli zostać przyjęci na WT, powinni byli studiować tam jako „klerycy diecezjalni" i resztę formacji i studium zakonnego uzupełniali $w$ ramach konsultacji z wyznaczonymi ojcami. Takie wykłady miały miejsce zwłaszcza w gronie wokół o. Metoděja Habáňa OP, który od 1957 r. działał w duszpasterstwie przy pielgrzymkowym kościele Marii Panny w Chlumie sv. Máŕí (pow. Sokolov), zaś uczestniczyli w nich również tercjarze i dalsze osoby świeckie.

${ }^{22} \mathrm{~Np}$. tajne wspólnoty wokół ks. Václava Dvořáka, potajemnie wyświęconego żonatego ks. Jana Konzala; grupy studyjne zorganizowane przez dra J. Zvěřinę, dra O. Mádra czy bpów Felixa M. Davídka i Stanislava Krátkého - wybitnych reprezentantów wspólnoty Koinotés (Kościoła podziemnego) lub też kursy niektórych kongregacji żeńskich (sióstr dominikanek, boromeuszek, cyrylo-metodianek).

${ }^{23} \mathrm{~Np}$. kursy w niemieckim Erfurcie w klasztorze urszulanek, gdzie odbywały się wykłady m.in. z katechetyki i teologii dla łącznie ok. 40 osób. 
sadzie do odnowy liturgii [Bugel 2013, 317-35] i relacji ekumenicznych). W 1968 r. założono tzw. Dzieło Odnowy Soborowej, które wsparli biskupi wracający $\mathrm{z}$ internowania. Sobór był jednakże interpretowany ze strony władzy państwowej (aspekt społeczny, solidarność międzyludzka), przez co dochodziło do jego dezinterpretacji. W tym okresie na terenie $\mathrm{RCz}$ działał jedyny katolicki WT w Pradze z siedzibą w Litomierzycach. W 1974 r. dziekanem został ks. L. Pokorný, a stopniowo dochodziło do wymiany grona pedagogicznego (nowi wykładowcy nie dorównywali jakościowo poprzednikom). Aż do końca jego kadencji stan zmierzał ku stagnacji spowodowanej koniecznością jak najmniejszej koniecznej współpracy z reżimem; kadencja jego następcy ks. Vymětala (1978-1989) naznaczona została przez głęboką stagnację wewnętrzną. Grono pedagogiczne wzięto prawie wyłącznie z wykładowców, którzy studiowali tylko na miejscowym wydziale i nie posiadali prawie żadnych publikacji, nie wspominając już nawet wyników badawczych. We wspomnianym okresie nie można więc utożsamiać całości teologii czeskiej tylko z tą akademicką. Poza WT istniały też struktury nieoficjalne o różnych koncepcjach, np. samizdat (rozpowszechniany głównie przez teologa O. Mádra, a oparty na tłumaczeniach artykułów zagranicznych przede wszystkim z obszaru języka niemieckiego), teologia na uchodźctwie rzymskim (K. Vrána, K. Skalický, J. Polc). Normatywnie wydział nadal stosował się do konstytucji apostolskiej Deus scientiarum Dominus. Po ogłoszeniu w dniu 15 kwietnia 1979 r. przez Jana Pawła II nowej konstytucji Sapientia Christiana (razem z przepisami wykonawczymi Kongregacji ds. Wychowania Katolickiego z 29 kwietnia 1979 r.) co prawda utworzona została komisja dla utworzenia nowego statutu WT, jednakże ten oceniony został przez SVC jako nieodpowiedni, gdyż urząd ten bazował na stanowisku, iż ciągle obowiązuje dekret rządowy o WT z 1950 r. Konstytucja Sapientia Christiana nie znalazła więc odzwierciedlenia $\mathrm{w}$ działalności wydziału aż do końca czasów totalitarnych pod koniec 1989 r. ${ }^{24}$, pomimo krytycznych uwag

\footnotetext{
${ }^{24} \mathrm{Na}$ dobór studentów nadal wpływ miał czeski UB, podobnie jak na dobór wykładowców. Poza nielicznymi wyjątkami (np. L. Tichý biblista, który w Litomierzycach mógł nauczać jedynie języków) wymagane było ich zaangażowanie $\mathrm{w}$ tzw. ruchu pokojowym (PiT). Aż do 1989 r. studia doktoranckie odbywały się więc zgodnie z Deus scienciarum Dominus.
} 
Stolicy Apostolskiej w tej sprawie [Cuhra 2001, 142, 192-93] ${ }^{25}$, tak samo jak w 1983 r. promulgowany Kodeks Prawa Kanonicznego ${ }^{26}$ (kan. 815-821). Na przekór wszelkim staraniom reżimu o obniżanie liczby kleryków, ich liczba wzrastała, tak iż w roku akademickim 1983-1984 studiowało ich w Litomierzycach 162 i możliwości przestrzenne seminarium i wydziału przestały być wystarczające. Na posesji seminarium duchownego dobudowano obiekt mieszkalny, by rozwiązać przynajmniej tę część problemu ${ }^{27}$. W roku akademickim 1989-1990 na studia przyjęto prawie wszystkich zgłaszających się, więc SVC zwrócił się do ordynariuszy $\mathrm{z}$ prośbą, by podnieśli zakres współfinansowania WT, gdyż Sekretariat nie miał już dalszych możliwości.

Taką sytuację na szczęście zastała jesienią 1989 r. tzw. rewolucja aksamitna, a także kanonizacja Agnieszki Praskiej w Rzymie dnia 12 listopada, w czym uczestniczyło wielu kleryków z Litomierzyc. Do rewolucji studenckiej klerycy dołączyli od razu, gdy tylko dnia 19 listopada została ona oznajmiona $\mathrm{w}$ mediach zachodnich - konkretnie $\mathrm{w}$ formie pisma protestacyjnego do premiera, w którym odmówili udziału w wykładach z tzw. nauk społecznych (de facto chodziło o indoktrynację marksistowską), domagali się śledztwa w sprawie masakry demonstracji studenckiej w Pradze z dnia 17 listopada. Następnie dołączyli do ogólnokrajowego strajku akademickiego i domagali się odejścia z WT wykładowców będących członkami zakazanego przez władze kościelne stowarzyszenia kapłańskiego SKD PiT ${ }^{28}$.

\footnotetext{
${ }^{25}$ Papież Jan Paweł II w styczniu 1982 r. zwrócił się do prezydenta CSRS G. Husáka w sprawie niemożliwego stanu WT i współpracy z reżimem komunistycznym. Kwestią tą zajął się również w ramach wizyty biskupów czechosłowackich ad limina w marcu 1982 r.

${ }^{26}$ Codex Iuris Canonici auctoritate Ioannis Pauli PP. II promulgatus (25.01.1983), AAS 75 (1983), pars II, s. 1-317 [dalej cyt.: KPK/83].Oficjalne tłumaczenie KPK/83 zostało w RCz wydane dzięki ks. M. Zedníčkowi dopiero w 1994 r., co bardzo odbiło się na poziomie znajomości obowiązującego prawa kanonicznego i jego rozumienia posoborowego wśród duchowieństwa czeskiego.

${ }^{27}$ Ówcześni klerycy wspominają „warunki skautingowe”, w jakich przyszło im żyć i studiować. W 1986 r. studenci I roku mieszkali w pokojach po 12 osób, a uczyli się w pomieszczeniach wspólnych dla 16 osób.

${ }^{28}$ Była to struktura podobna do Ruchu Księży Patriotów w PRL. Chodziło o następujących wykładowców: dziekana prof. F. Vymětala i prodziekana prof. G. Čejkę, doktorów J. Hubera, H. Wiesnera, F. Janhubę i M. Adámka. Kard. Tomášek zaapelował do nich, by przyznali, że nie powinni być wykładowcami, zaś o ile by tego odmówili, należało odebrać im misję kanoniczną. W grudniu 1989 r. Tomášek zaproponował na zwolnione stanowiska nominacje: J. Kadleca (historia Kościoła), T. Halíka (psychologia i socjologia, jakie zastąpią marksistowskie nauki społeczne), J. Hermacha (Stary
} 
Ich postawa pobudziła bierne miasto Litomierzyce wraz z okolicą, gdzie klerycy zaktywizowali ludność zaznajamiając $\mathrm{z}$ aktualną sytuacją polityczną i wciągając w protesty. Semestr letni roku akademickiego 1989-1990 przebiegał pod znakiem przygotowań do powrotu WT pod egidą Uniwersytetu im. Karola w Pradze oraz do wznowienia samodzielnego WT w Ołomuńcu.

\section{ODNOWA UNIWERSYTECKICH STUDIÓW TEOLOGICZNYCH W LATACH 1990-2000}

\subsection{Powrót na łono uniwersytetów i odnowa legislacyjna}

Jedną z konsekwencji przywrócenia wolności religijnej była też odnowa działalności wydziałów teologicznych bez nadzoru państwowo-politycznego. Ponieważ do relegacji WT z uniwersytetów doszło za pośrednictwem ustawy, konieczne było, by ich powrót przebiegł w ten sam sposób. Taka była geneza ustawy nr 163/1990 ZU o WT, która w maju 1990 r. w $§ 1$ deklarowała: Rzymskokatolicki WT w Pradze z siedzibą w Litomierzycach włącza się do Uniwersytetu im. Karola w Pradze. Przywrócony zostaje Cyrylo-Metodiański WT w Ołomuńcu i włączony do Uniwersytetu im. Palackého w Ołomuńcu. Eryguje się Rzymskokatolicki Cyrylo-Metodiański WT Uniwersytetu im. Komenského w Bratysławie, który włączony zostaje do Uniwersytetu im. Komenského w Bratysławie. Ustanawia się Greckokatolicki WT, który włączony zostaje do Uniwersytetu im. P.J. Šafárika w Koszycach. Praski WT rozpoczął nowy rok akademicki pod nazwą Katolicki WT, którą posiada do dziś, a wydział ołomuniecki jako Cyrylo-Metodiański WT ${ }^{29}$. Uroczysta

Testament), J. Hřebíka (pedagogika, katechetyka), S. Sousedíka (filozofia chrześcijańska), M. Vlka (teologia fundamentalna) i V. Wolfa (teologia dogmatyczna). Niektórzy z nich jednakże nie mogli zacząć pracować na wydziale z powodu innych zadań w Kościele czeskim (np. Vlk został biskupem w Czeskich Budziejowicach) [Cuhra 2001, 305].

29 W nazwie oryginalnej słowo „bohoslovecká”, będące starszą rodzimą wersją przymiotnika „teologická” zastąpiono w 1992 r. tym nowym wyrazem [we współczesnym j. czeskim wyraz „bohoslovecký” kojarzy się bardziej z rzeczownikiem „bohoslovec", oznaczającym kleryka; natomiast w czasach międzywojennych określano nim teologa]. Za pewną ciekawostkę można uznać to, iż w czasach totalitaryzmu komunistycznego Stolica Apostolska w Annuario Pontificio w zasadzie nie uwzględniała zmiany na terytorium CSRS. W 1990 r. przy praskim WT (wówczas jeszcze z siedzibą w Litomierzycach) podany został rok założenia 1347, zaś przy wydziale ołomunieckim 
inkorporacja praskiego WT miała miejsce 24 września 1990 r., a ołomunieckiego 22 października 1990 r. Przywrócone zostały też seminaria arcybiskupie w Pradze - Dejvicach (głównie dla kleryków prowincji czeskiej) i w Ołomuńcu (dla kleryków prowincji morawskiej) ${ }^{30}$. W latach 1990-1991 powstał jeszcze dalszy WT, zapewniający studia głównie dla osób świeckich, w Czeskich Budziejowicach.

Pierwsza odnowiona ustawa o szkolnictwie wyższym z $1990 \mathrm{r} .{ }^{31}$ poświęcała WT $\S 32$, który jedynie stwierdzał, iż przepisy ustawy dotyczą tych wydziałów w sposób analogiczny. Ustawa nr 308/1991 ZU o wolności religijnej, Kościołach $i$ zwiazkach wyznaniowych stwierdzała, że Kościoły i związki wyznaniowe mają prawo $\mathrm{w}$ ramach spełniania swego posłannictwa, zwłaszcza nauczać i wychowywać swych pracowników duchownych i świeckich we własnych szkołach i innych zakładach wychowawczych i na akademickich uczelniach teologicznych oraz WT z zachowaniem warunków określonych przez przepisy prawa natury ogólnej ${ }^{32}$. Ustawa o szkolnictwie wyższym z 1998 r. dodatkowo potwierdza autonomię w przyjmowaniu norm WT dopiero po ich zatwierdzeniu przez konkretny Kościół ${ }^{33}$, używanie tytułów akademickich ThLic. i Th.D. specyficznych w sferze teologii katolickiej ${ }^{34}$. Ostatnia nowelizacja tej ustawy ujednoliciła skrót dla doktoratu z teologii na ogólnie przyjęty $\mathrm{Ph} . \mathrm{D}$., pisany za nazwiskiem ${ }^{35}$.

(bez adresu pocztowego) rok 1570, zaś oba wydziały prezentowano jako mieszczące się w ramach uniwersytetów państwowych, zob. Annuario Pontificio 1990, s. 1596.

${ }^{30}$ Własnego seminarium duchownego, jakie mogłoby istnieć w każdej diecezji, jak zakłada to KPK/83 w kan. 237, nie dało się zrealizować i nadal nie jest możliwe w warunkach czeskich z powodu niskiej ilości kleryków. Zakony zwykle zapewniają formację duchową we własnych instytutach, zaś dla tej intelektualnej korzystają z usług któregoś z WT lub wysyłają swych członków na studia za granicę (np. dominikanie część studiów odbywają we Francji).

${ }^{31}$ Ustawa nr 172/1990 ZU o szkolnictwie wyższym.

${ }^{32}$ Ustawa nr 308/ $1991 \mathrm{ZU}$ o wolności religijnej, Kościołach i zwiq̨zach wyznaniowych, $\S 6$ ust. 1 e.

${ }^{33}$ Ustawa nr 111/1998 ZU o szkolnictwie wyższym i zmianie $i$ uzupetnieniu dalszych ustaw, §33.

${ }^{34}$ Tamże, $\S 46$ ust. 5 e.

${ }^{35}$ Co do wyjaśnienia czeskich tytułów z teologii por. ustawa $\mathrm{nr}$ 137/ 2016, zmieniająca ustawę $\mathrm{nr}$ 111/1998 ZU o szkolnictwie wyższym $i$ zmianie $i$ uzupetnieniu dalszych ustaw, nr 289-290: w § 99 ust. 10 ustawy nr 111/1998 ZU tekst nadający tytuł w zakresie teologii o skrócie Th.D., zostaje zniesiony. Do $§ 99$ ust. 10 umieszcza się nowy ust. 11, który brzmi: Absolwenci studium w programach studiów doktoranckich w zakresie teologii, którzy zgodnie z $§ 47$ ust. 5 uzyskali tytuł akademicki „doktor teologii” (o skrócie „Th.D.” pisanym za nazwiskiem), mogą prosić właściwą uczelnię 
Zarówno praski, jak i ołomuniecki WT są z kościelnego punktu widzenia wydziałami kościelnymi (choć istniejącymi na uniwersytetach państwowych). Dlatego też po 1990 r. w końcu uwzględnione zostały postanowienia konstytucji Sapientia Christiana w ramach ustanawiania wykładowców i udzielania misji kanonicznych bez ingerencji władz państwowych, co do tej pory nie było możliwe.

\subsection{Praski katolicki wydział teologiczny w latach 1990-2000}

Praski WT powrócił w 1990 r. na łono Uniwersytetu Karola i jako jedyny nie musiał zostać ponownie odnowiony prawnie, a jedynie przywrócony do należnej mu pozycji. Wejście w system demokratyczny nie przebiegło tu jednak zupełnie bezproblemowo i uczelnia w latach 1994-2003 przeszła przez poważny kryzys wewnętrzny, który odbił się również na poziomie studiów. Dziekanem już w styczniu 1990 r. został filozof i dogmatyk ks. prof. V. Wolf, nominowany przez abpa praskiego F. Tomáška (wybór przez senat akademicki nie był wówczas możliwy, gdyż brakowało odpowiednich przepisów państwowych i przepisów wewnętrznych wydziału), który pozostał na tym stanowisku aż do 1997 r. Wolfovi osobiście i wydziałowi jako instytucji zarzucano $\mathrm{w}$ tym czasie zbytni konserwatyzm i oderwanie od realiów współczesności ${ }^{36}$. W okresie 1997-2002 dziekanem został historyk kościelny J.V. Polc, lecz istotne zmiany nie nastąpiły. W styczniu 2002 r., w obliczu groźby cofnięcia akredytacji, rektor Uniwersytetu Karola (współpracując z praskim abpem M. Vlkiem) mianował administratorem

wyższą o zastąpieniu tego tytułu tytułem akademickim „doktor” (o skrócie „Ph.D.” pisanym za nazwiskiem). Zaświadczenie o zastąpienie wspomnianego tytułu akademickiego zostanie im na ich prośbę wydane przez właściwą uczelnię wyższą.

${ }^{36}$ Kryzys w latach 1994-2003 tkwił w niezrozumieniu przez dziekana ukierunkowania działalności wydziału. Wolf traktował WT jako szkołę dla księży i kandydatów do seminarium. Kryzys pogłębił się jeszcze bardziej, gdy w 1996 r. odejść musiał I.O. Štampach OP i niski poziom nauczania zaatakował kolejny ksiądz pochodzący z podziemia, T. Halík. Obaj podkreślali konieczność reformy nauczania w duchu Vaticanum II. Świeccy i studenci z innych wydziałów mieli znacznie ograniczone możliwości studiowania. Dnia 8 grudnia 1999 r. senat akademicki wybrał Wolfa dziekanem po raz trzeci. Zaczęły się spory o prawomocność tego wyboru, gdyż według przeważającej interpretacji statutów KTF UK możliwa była jedynie podwójna kadencja, zaś zmiana znosząca to ograniczenie i wcześniej przyjęta przez senat nie miała wymaganego zatwierdzenia przez Kongregację, tak samo ustawa o szkolnictwie wyższym nie dopuszczała takiej możliwości. W końcu dnia 28 lutego 2000 r. abp praski z tytułu swej funkcji Wielkiego Kanclerza zawetował wybór, w czym poparła go większość biskupów czeskich. 
WT prof. M. Lobkowicza, powierzając mu przygotowanie koniecznych reform (przyjęcie wewnętrznych dokumentów statutowych, które byłyby w zgodzie z ustawodawstwem kościelnym i państwowym, utworzenie senatu akademickiego ${ }^{37}$, odnowa kadry pedagogicznej). Kryzys wokół V. Wolfa został rozwiązany dopiero w lutym 2002 r., gdy został odwołany również z funkcji kierownika katedry. Został pozbawiony misji kanonicznej i rozwiązano z nim umowę o pracę. Wydział działał w warunkach zarządu nadzwyczajnego: w maju 2002 r. czeskie MEN za radą Komisji Akredytacyjnej podjęło decyzję o tymczasowym cofnięciu akredytacji i ograniczeniu kompetencji WT (senat akademicki i Rada Wydziału były zamknięte już od końca 2001 r.). W grudniu 2002 r. dziekan Polc złożył rezygnację i jego uprawnienia przejął rektor. Stan zarządzania nadzwyczajnego skończył się dopiero na początku 2003 r., gdy po utworzeniu norm wydziału zatwierdzonych przez Kongregację ds. Wychowania Katolickiego i ogłoszeniu nowych wyborów do senatu, Ministerstwo zdecydowało o przywróceniu praw senatu i Rady Wydziału, a w marcu tegoż roku również dziekanowi KTF.

\subsection{Ołomuniecki wydział teologiczny w latach 1990-2000}

Ołomuniecki WT został na nowo utworzony w Uniwersytecie im. Palackého dnia 22 października 1990 r., choć rok akademicki rozpoczęto już 8 października. Abp F. Vaňák mianował pierwszym dziekanem V. Tkadlčíka, stopniowo odnawiano grono pedagogiczne, a wydział przejął swą pierwotną siedzibę. Dopiero w 1991 r. został zgodnie z przepisami prawa państwowego i kościelnego wybrany senat akademicki, który nowym dziekanem wybrał dotychczasowego prodziekana, biblistę L. Tichého. Doszło do poszerzenia posłannictwa wydziału, który oprócz kleryków kształcił również świeckich. W 1997 r. dziekanem został pastoralista P. Ambros. Poza remontem zaniedbanego budynku historycznego potrzebne było stworzenie biblioteki, wyposażenie katedr i uzupełnienie grona pedagogów. Wśród tych byli z początku jeszcze ci, którzy odbyli studia III stopnia po wojnie w Rzymie lub studia II stopnia na ołomunieckiej filii litomierzyckiego WT w latach 70. Uzupełniani jednak byli stopniowo młodszymi, powracającymi ze studiów specjalistycznych z zagranicy. Po odnowieniu uczelnia posiadała 6 katedr,

${ }^{37} \mathrm{~W} \mathrm{RCz}$ senat akademicki pełni wobec kierownictwa wydziałów i uniwersytetów funkcję organu kontrolnego i współdecydującego. 
wprowadzono państwowe egzaminy magisterskie. Od wejścia w życie nowej ustawy o szkolnictwie wyższym w 1998 r. obowiązkowe stały się obrony prac magisterskich, poszerzono ofertę nauki języków współczesnych [Pojsl 2010, 55], komputeryzowano pomieszczenia, otwierane były nowe kierunki studiów. W 2006 r. utworzono nową Katedrę chrześcijańskiej pracy społecznej, którą kierował prof. H. Pompay z niemieckiego Freiburga [tamże, 58], a na wydział przyszli zagraniczni specjaliści nieobciążeni dziedzictwem komunizmu. Od 1998 r. uczelnia oferuje studia III stopnia na kierunkach teologii biblijnej, systematycznej i praktycznej (w ramach których istnieje kilka dalszych specjalizacji). Praca naukowa wykładowców realizuje się tak poprzez projekty grantowe, jak też w ramach tzw. centrów badawczych.

\subsection{Wydział teologiczny w Czeskich Budziejowicach w latach 1991-2000}

WT stał się jednym z założycielskich placówek nowopowstałego Uniwersytetu Południowoczeskiego w Czeskich Budziejowicach, do czego doszło w 1991 r. przez połączenie istniejących dotychczas samodzielnie wydziałów pedagogicznego i administracyjno-ekonomicznego a erygowaniem kilku dalszych. W 2009 r. ilość wydziałów podniosła się do 8. WT na tym uniwersytecie nawiązał do studium dla księży, utworzonego (wraz z seminarium) już w 1790 r. Działalność tej diecezjalnej szkoły teologicznej, zlikwidowanej w 1950 r., wznowiona została w 1991 r. decyzją uniwersyteckiego senatu akademickiego i zatwierdzeniem przez ówczesnego biskupa diecezjalnego dra A. Liškę na prawach instytutu diecezjalnego. Pierwszym dziekanem WT został od 1992 r. ks. K. Flossmann, biblista starotestamentalny, a po nim uczelnią kierowali księża, którzy powrócili z zagranicy: F. Kopecký i K. Skalický [Horák 2011, 233]. Wydział czeskobudziejowicki od swego wznowienia starał się o wytworzenie szerszych więzów z innymi kierunkami humanistycznymi i bycie platformą kontaktu między studentami innych wydziałów, a co za tym idzie, o wychodzenie naprzeciw zwłaszcza studentom świeckim (kierunek nauczycielstwo religii). Spośród kandydatów do kapłaństwa studiowali tu raczej tylko członkowie niektórych instytutów zakonnych (salezjanie i petryni). Natomiast klerycy diecezjalni studiują na WT w Pradze, gdzie formację odbywają razem $\mathrm{z}$ pozostałymi $\mathrm{z}$ czeskiej prowincji kościelnej w tamtejszym seminarium. Czeskobudziejowicki WT oprócz kie- 
runków teologicznych stopniowo poszerzył swą ofertę także o inne (humanistyka, pedagogika, praca socjalno-charytatywna, itp.) [tamże, 232]. Wydział mieści się w budynku dawnego seminarium diecezjalnego z $1950 \mathrm{r}$.

\section{KATOLICKIE WYDZIAŁY TEOLOGICZNE W REPUBLICE CZESKIEJ W XXI WIEKU}

\subsection{Ogólne ramy prawne działalności wydziałów teologicznych}

Podstawową obowiązującą normą prawa świeckiego dla WT w $\mathrm{RCz}$ jest ustawa $\mathrm{nr}$ 111/1998 ZU o szkolnictwie wyższym (nowelizowana ostatnio w 2018 r.), która w § 33 ust. 4 określa, iż wewnętrzne normy WT przedkładane są do zatwierdzenia senatowi akademickiemu uczelni po tym, jak zaaprobowane zostały przez konkretny Kościół, o ile obowiązek zatwierdzenia wynika $\mathrm{z}$ wewnętrznych norm tego Kościoła czy wspólnoty wyznaniowej. W ten sposób zabezpieczony został nadzór kościelny we współpracy z prawodawstwem czeskim, czyli konkretna forma współpracy Kościoła z państwem według zasad określonych przez Sobór Watykański $\mathrm{II}^{38}$, gdyż nie ma na razie podpisanej umowy konkordatowej między RCz a Stolicą Apostolską, jaka powinna regulować również te kwestie. Od tzw. rewolucji aksamitnej aż do 2018 r. normą kościelną w sprawie działalności czeskich kościelnych WT była konstytucja apostolska Jana Pawła II Sapientia Christiana; od pierwszego dnia roku akademickiego 2018/2019 zastąpiona została przez konstytucję apostolską papieża Franciszka Veritatis gaudium ${ }^{39}$ i do niej nawiązujących Ordinationes. Normy te są obecnie implementowane także w środowisku czeskim: praski i ołomuniecki WT - jako wydziały kościelne w ramach innego uniwersytetu (VG I § 2) przygotowują rewizję swych statutów i reguł studyjnych dla zatwierdzenia ich przez Kongregację ds. Wychowania Katolickiego przed dniem 8 grudnia 2019 r., jak domaga się tego

38 Sacrosanctum Concilium Oecumenicum Vaticanum II, Constitutio Pastoralis de Ecclesia in mundo huius temporis Gaudium et spes (7.12.1965), AAS 58 (1966), s. 1025$116, \mathrm{nr} 75$.

${ }^{39}$ Francesco, Constitutione apostolica Veritatis gaudium circa le Università e le Facoltà Ecclesiastiche (8.12.2017), http://w2.vatican.va/content/francesco/it/apost_ consti tutions/documents/papa-francesco_costituzione-ap_20171208_veritatis-gaudium.html [dalej cyt.: VG] [dostęp: 6.02.2019]. 
art. 89 § 1 VG (jednakże oba WT umówiły się, że będą prosić o odroczenie zgodnie z art. 92 VG). Procedura ta pokrzyżowana została przez zmiany w czeskim systemie akredytacji, tak iż od roku akademickiego 2019/2020 WT będą realizować swe nowo akredytowane programy studiów pod nadzorem nie tylko organów szkolnictwa wyższego, ale też jako podlegające zewnętrznej ocenie Agendy Stolicy Apostolskiej ds. Oceny i Wspierania Uniwersytetów i Wydziałów Kościelnych (AVEPRO) ${ }^{40}$. Ostatnim uzupełnieniem do VG jest List okólny skierowany do uniwersytetów i wydziałów kościelnych przez Kongregację ds. Wychowania Katolickiego (rozesłany ordynariuszom w grudniu 2018 r.), w którym podano punkty orientacyjne dla aplikowania zasad VG i do nich odnoszących się przepisów wykonawczych ${ }^{41}$.

\subsection{Praski wydział teologiczny}

Katolicki WT w Pradze skonsolidował się realnie dopiero w XXI w. W 2003 r. nowym dziekanem został wybrany przez senat akademicki i potwierdzony przez Kongregację L. Armbruster SJ, filozof, który prawie pięć dekad spędził za granicą, pracując głównie na Uniwersytecie Katolickim w Tokio. Funkcję pełnił do 2010 r. Za jego kadencji studia dzienne z teologii otwarto też dla świeckich, włącznie z kobietami. Po nim został dziekanem dogmatyk, ks. P. Brož. Ten po zakończeniu kadencji i tzw. semestrze sabatycznym w Rzymie zdecydował się na zakończenie swej działalności akademickiej i na własną prośbę powrócił do duszpasterstwa w diecezji Hradec Králové. Jego następcą i równocześnie pierwszym dziekanem świeckim w dziejach wydziału stał się w 2018 r. historyk kościelny V. Novotný. Wydział posiada wewnętrzne normy zgodne $\mathrm{z}$ ustawą o szkolnictwie wyższym oraz z przepisami kościelnymi, działający senat akademicki, zaś formację przyszłych duchownych (z czeskiej prowincji kościelnej) zapewnia praskie metropolitalne seminarium duchowne.

${ }^{40}$ Por. VG, Ordinationes, I $\S 2$. AVEPRO erygował Benedykt XVI jako instytut stowarzyszony ze Stolicą Apostolską (zgodnie z art. 186 i 190-191 Pastor Bonus) w 2007 r. w związku z włączeniem się uniwersytetów i wydziałów kościelnych w proces boloński (przebiegający od 1999 r.), do czego Stolica Apostolska dołączyła w 2003 r. Zob. AAS 101 (2009), s. $12-20$.

${ }^{41}$ Zob. http://www.educatio.va/content/dam/cec/Documenti/circolare\%20italiano.pdf [dostęp: 21.02.2019]. Oficjalny przekład czeski VG oraz do niego nawiązujących dyrektyw na razie się nie ukazał, ale obecnie finalizowane są jego przygotowania. 


\subsection{Wydział teologiczny w Ołomuńcu}

Cyrylo-Metodiański WT w Ołomuńcu jest, podobnie jak ten praski, wydziałem kościelnym (kan. 815-821 KPK/83). Wielkim kanclerzem jest metropolita Ołomuńca. Dzięki wyższemu poziomowi religijności na Morawach wydział ten ma większą liczbę studentów teologii, niż ten praski. W tym samym mieście znajduje się też metropolitalne seminarium duchowne (gdzie przygotowywani są do kapłaństwa kandydaci z diecezji brneńskiej, ostrawsko-opawskiej i archidiecezji ołomunieckiej) oraz ogólnopaństwowy konwikt teologiczny dla przyszłych kleryków. Grono pedagogiczne stabilizowało się po 2000 r., a wciąż się odnawia. W 2007 r. w budynku uczelni otwarto kaplicę wydziałową, w 2015 r. odrestaurowano w historycznych proporcjach aulę. Obecnie WT liczy 8 katedr (filozofii i patrologii, nauk biblijnych, teologii systematycznej, historii Kościoła i prawa kanonicznego, teologii liturgii, teologii pastoralnej i duchowości, wychowania chrześcijańskiego, oraz chrześcijańskiej pracy społecznej). Dla potrzeb całego uniwersytetu działa duszpasterstwo akademickie przy erygowanej w styczniu 2006 r. parafii studenckiej przy kościele jezuickim Panny Marii Śnieżnej. Wydział zmuszony został nie ograniczać się jedynie do kierunków teologicznych, ale do zaproponowania coraz większej ilości kierunków powiązanych przynajmniej częściowo z teologią: z zakresu pracy społecznej, charytatywnej i humanitarnej (w przeciągu kilku lat ilość i nazwy zmieniały się zgodnie z wytycznymi akredytacyjnymi) oraz pedagogiki społecznej. W latach 2002-2005 na wydziale odbywały się także studia humanistyczne, które jednak zamknięto ze względu na brak zainteresowania. Wydziałem kierował przez dwie kadencje jezuita P. Ambros do 2003 r., kiedy zastąpił go biblista, salezjanin P. Chalupa. Po nim w latach 2006-2014 funkcję tę pełniła pierwsza w historii czeskiej kobieta, biblistka i dominikanka G. Vlková. Obecnie funkcję dziekana, także w drugiej już kadencji, pełni słowacki psycholog dominikański prof. P. Tavel.

\subsection{Wydział teologiczny w Czeskich Budziejowicach}

WT w Czeskich Budziejowicach musiał ok. 2000 r. zareagować na spadek zainteresowania kierunkiem nauczycielstwo religii, który dotychczas miał najwięcej absolwentów. Obniżenie liczby studentów widoczne było również na kierunkach teologicznych (teolog i asystent duszpasterski), 
skoro na terenie Czech (w odróżnieniu od Moraw) religii prawie nie uczy się w szkołach państwowych [Horák 2011, 234]. Obecnie WT oferuje zarówno kierunki teologiczne, filozofię i religioznawstwo, jak i kierunki socjalnocharytatywne i pedagogiczne. Z kanonicznego punktu widzenia uczelnia ta nie jest wydziałem kościelnym (i wydaje się, że nawet nie stara się o ten status, gdyż umożliwia to pewną swobodę tak w realizowaniu nowych kierunków studyjnych, jak też w kwestii zatwierdzania przepisów wewnętrznych czy też nominacji nauczycielskich, bez ścisłego współdziałania z Kongregacją ds. Wychowania Katolickiego) i pozostaje na poziomie diecezjalnej szkoły teologicznej. Konsekwencją tego jest jednak to, że tytuły akademickie nadane przez ten wydział nie posiadają wartości kanonicznej. Wydział jednak nie pozostaje zupełnie poza nadzorem kościelnym, gdyż zgodnie ze statutem Uniwersytetu Południowoczeskiego (art. 3 ust. 2), biskup czeskobudziejowicki pełni funkcję tzw. moderatora WT: zatwierdza jego statut, pełni wobec niego odpowiednie funkcje zgodnie z kan. 806 KPK/83, odpowiada za prawowierność nauczania i zachowywania wytycznych Stolicy Apostolskiej i konferencji biskupów, daje nihil obstat dla wybranego dziekana i mandantum dla wykładowców dyscyplin teologicznych, ustanawia duszpasterza akademickiego i co trzy lata kieruje sprawozdanie w sprawie wydziału dla Kongregacji ds. Wychowania Katolickiego.

Dziekanami byli w latach 1999-2002 pastoralista i salezjanin J. Dolista, prawnik i kanonista J. Kašný (2002-2008), zaś w latach 2008-2016 katolicki filozof świecki T. Machula, który został rektorem uniwersytetu, tak więc w funkcji dziekana zastąpił go kolejny świecki, historyk Kościoła R. Svoboda, który kieruje wydziałem po dzień dzisiejszy.

\section{ZAKOŃCZENIE}

Po interwencjach władz komunistycznych w Czechosłowacji jedynym oficjalnym WT aż do 1990 r. pozostał Cyrylo-Metodiański WT w Pradze z siedzibą w Litomierzycach (jego działalność była częściowo lokowana do Ołomuńca w formie tamtejszej filii na przełomie lat 60. i 70.). Taki sposób nauczania teologii był specyficzny nie tylko, co do formy, ale też i co do treści: przeznaczony wyłącznie do kształcenia przyszłych księży dla duszpasterstwa, a więc ukierunkowany jedynie na podstawowe prawdy wiary i obyczajów oraz egzegezę Pisma Świętego. Była to też teologia bez 
należytego magisterium i bez kontaktu z biskupami. Faktycznym autorytetem były polityczne stowarzyszenia kapłańskie: Ogólnopaństwowy Pokojowy Komitet Duchowieństwa Katolickiego, później Ruch Pokojowy Duchowieństwa Katolickiego, zastępującego biskupów w kierowaniu Kościołem lokalnym. Działalność świeckich nie była w ogóle umożliwiana, podobnie jak utrzymywanie relacji ekumenicznych, sprowadzanie literatury religijnej i teologiczna praca naukowa. Wydziały wraz z teologią tego okresu zamknięte były w sobie, starając się o przetrwanie [Skoblík 2019]. Po przewrocie w 1989 r. umożliwiono powrót studiów teologicznych na łono uniwersytetów, gdzie mają sobie należne miejsce, co w przypadku praskiego WT udało się dopiero w nowym tysiącleciu. $\mathrm{RCz}$ posiada więc obecnie dwa WT (w sensie wydziałów kościelnych), istniejące na uniwersytetach państwowych; jeden WT (w sensie diecezjalnej szkoły teologicznej); dwa seminaria duchowne (w Pradze dla kleryków z diecezji czeskich i w Ołomuńcu dla tych z morawsko-śląskich; klerycy zakonni kierowani są do obydwu) oraz przygotowawczy konwikt teologiczny w Ołomuńcu. Jest to stan maksymalny, jaki mógł zostać osiągnięty - zaczynają się nawet pojawiać dyskusje nt. jego możliwego utrzymania na dłuższą metę. Po wznowieniu działalności moment największego rozkwitu WT przypadał na przełom tysiąclecia. Dopiero przyszłość pokaże, czy w warunkach czeskiego zsekularyzowanego społeczeństwa uda się utrzymać taki model, lub czy przeważać zaczną na tych uczelniach inne niż teologiczne kierunki studiów, jakie od 2000 r. wciąż się rozwijają. Malejąca ilość powołań duchownych i zakonnych niesie ze sobą niższe zainteresowanie studium teologii. To stanowić może jednak też wyzwanie do poszukiwania nowych dróg i dialogu, starań o przedkładanie przesłania Chrystusowego w sposób bardziej aktualny i zrozumiały. WT muszą potrafić połączyć w sobie proces kształcenia i formacji z twórczymi badaniami naukowymi. Jeżeli chcą zachować swą tożsamość także dzisiaj, jako konieczne jawi się nie tylko znalezienie równowagi w ofercie kierunków studyjnych, ale też zachowanie zdolności do osobistego świadectwa pedagogów, przedkładających studentom nie tylko wiedzę naukową, ale też chrześcijańskie doświadczenie Bożej obecności w życiu człowieka i Kościoła. 


\section{PIŚMIENNICTWO}

Balík, Stanislav, i Jiří Hanuš. 2007. Katolická církev v Československu 1945-1989. Brno: Centrum pro studium demokracie a kultury.

Bugel, Walerian. 2013. "Sacrosanctum concilium» - initium culmenque instaurationis Ecclesiae? Kontekst i uwarunkowania historyczne wprowadzania reformy liturgicznej Soboru Watykańskiego II w warunkach czechosłowackich." Liturgia sacra. Liturgia - musica - ars 19, nr 2 (42): 317-35.

Cekota, Vojtěch. 1996. "Teologická fakulta (1860-1996).” In Padesát let $z$ dějin obnovené univerzity, ed. Miloslav Pospíchal, 39-57. Olomouc: Vydavatelství Univerzity Palackého.

Cuhra, Jaroslav. 2001. Československo-vatikánská jednání 1968-1989. Praha: Ústav pro soudobé dějiny AV ČR.

Černušák, Tomáš, Augustin Prokop, and Damián Němec. 2001. Historie dominikánů v českých zemích. Praha: Krystal OP.

Demel, Zdeněk. 2001. "Po stopách jednoho smutného výročí." Studia Theologica 3:63-65.

Horák, Záboj. 2011. Církve a české školství. Praha: Grada.

Jäger, Petr. 2009. "Svoboda vyznání a právní poměry církví a náboženských společností v letech 1948-1989.” In Michal Bobek, Pavel Molek, and Vojtěch Šimíček, Komunistické právo v Československu, 781-82. Brno: Mezinárodní politologický ústav, Masarykova univerzita.

Kaplan, Karel. 1993. Stát a církev v Československu v letech 1948-1953. Brno: Doplněk.

Novotný, Vojtěch. 2007a. Katolická teologická fakulta 1939-1990. Praha: Karolinum.

Novotný, Vojtěch. 2007b. Teologie ve stínu. Praha: Karolinum.

Pojsl, Miloslav. 2010. "Cyrilometodějská bohoslovecká fakulta v Olomouci v letech 1968-1974." In Cyrilometodějská teologická fakulta Univerzity Palackého v Olomouci v letech 1990-2010, 38-47. Velehrad: Univerzita Palackého v Olomouci.

Skoblík, Jiří. 2019. "Večer věnovaný námětu «1000 let české teologie»." http://ktf.cuni.cz/ skoblik/komentare/teologie.htm [dostęp: 27.02.2019].

Vlček, Vojtěch. 2004. Perzekuce mužských řádů a kongregací komunistickým režimem 1948-1964. Olomouc: Matice cyrilometodějská.

\section{Pozycja prawna katolickich wydziałów teologicznych na terytorium Republiki Czeskiej od 1950 roku}

\section{Streszczenie}

Katolickie wydziały teologiczne na obecnym terytorium Republiki Czeskiej były aktem normatywnym w 1950 r. jednostronnie wydzielone z grona uniwersytetów, na których funkcjonowały często od ich historycznych początków. Jedynym oficjalnym wydziałem teologicznym do 1990 r. był Wydział Teologiczny Cyryla i Metodego w Pradze z siedzibą w Litomerice (którego oddział był częściowo zlokalizowany w Ołomuńcu w latach 1968-1974 jako miejsce pracy tego wydziału). Do grona uniwersytetów był możliwy powrót dopiero w 1990 r. po tzw. aksamitnej rewolucji. Od tego czasu ma 
miejsce stopniowe budowanie wydziałów teologicznych i poszukiwanie ich specyficznego miejsca w czeskim społeczeństwie. Artykuł podsumowuje proces ich wydzielenia i powrotu w perspektywie historii i prawa kanonicznego. Utworzenie wydziałów teologicznych ze strony Kościoła jest jednak w obecnym systemie prawnym Republiki Czeskiej ponownie jednym $\mathrm{z}$ wielu przejawów autonomii kościołów i związków wyznaniowych gwarantowanych przez prawo.

Słowa kluczowe: wydziały teologiczne w Republice Czeskiej; wydziały kościelne; reżim komunistyczny; nadzór państwowy nad Kościołem

\section{The Legal Position of Catholic Theological Faculties on the Territory of the Czech Republic since 1950}

\section{Su m m a ry}

In 1950, Catholic faculties of theology on the territory of the present-day Czech Republic were unilaterally excluded from the university structures by statute, despite their frequent affiliation with universities from the beginning. Until 1990, the only official theological faculty was the Saints Cyril and Methodius Faculty of Theology in Prague, with its seat in Litoměřice (the branch of which was partially located in Olomouc in 1968-1974 as an actually operating facility). The reincorporation of those faculties was not possible until 1990, after the Velvet Revolution. Since then we observe a gradual growth of theological faculties and a search for their unique place within the Czech society. The article recapitulates the process of their isolation and reincorporation in the historical and canon law perspective. However, the Church's establishment of theological faculties is again one of the many manifestations of the autonomy of the Church and religious organisations, which is guaranteed by law in the current legal order of the Czech Republic.

Key words: faculty of theology in the Czech Republic; Church faculties; Communist regime; state supervision over the Church

Information about Author: Monika MENKE, PH.D. - assistant professor in the Department of Church History and Canon Law, Sts. Cyril and Methodius Faculty of Theology at the Palacký University of Olomouc; Na Hradě 2, 77900 Olomouc, Czech Republic; e-mail: monika.menke@upol.cz; https://orcid.org/0000-00022814-2524 